\title{
MENINGKATKAN KEMAMPUAN MEMBACA PERMULAAN MELALUI KEGIATAN MENDONGENG VARIASI MEDIA DI KB PAUD
}

\author{
Alfin Zainun Faiz \\ KB PAUD PKK Wonojoyo Kediri \\ email: Alfhyn.fa@gmail.com
}

\begin{abstract}
Improving The Ability To Read The Beginning Through The Storytelling Activity A Media Variations In KB PAUD. This study aims to improve the ability to read the beginning through the activities of storytelling with media variations and know the process of improving the ability to read the beginning through the storytelling activities with media variations. The research method used is action research with Kemmis and Taggart model. Research subjects were $16 \mathrm{~KB}$ children. This study was conducted in two cycles consisting of eight meetings in a cycle so that there were sixteen meetings. Technique of collecting data is done through observation, interview, and documentation. Data analysis technique used in this research is qualitative and quantitative data analysis. Qualitative data analysis used is data reduction, data display, and verification. Quantitative data analysis is used to find out the percentage of reading ability improvement after the beginning of the implementation of the action using the graph. The result of the research shows that the improvement of the understanding of children's geometry can be seen from the average prasiklus value of 58, the average of cycle I average 77, and cycle II with an average of 90 . So it can be concluded that the activities of storytelling with media variations can improve the ability to read the beginning
\end{abstract}

Key words: Early Reading Ability, Storytelling, Media Variation

\begin{abstract}
Abstrak : Meningkatkan Kemampuan Membaca Permulaan Melalui Kegiatan Mendongeng Variasi Media Di KB PAUD. Penelitian ini bertujuan untuk meningkatkan kemampuan membaca permulaan melalui kegiatan mendongeng dengan variasi media serta mengetahui proses meningkatkan kemampuan membaca permulaan melalui kegiatan mendongeng dengan variasi media. Metode penelitian yang digunakan adalah penelitian tindakan dengan model Kemmis dan Taggart. Subjek penelitian sebanyak 16 anak KB. Penelitian ini dilakukan dalam dua siklus yang terdiri dari delapan kali pertemuan dalam satu siklus sehingga ada enam belas kali pertemuan. Teknik pengumpulan data dilakukan melalui observasi, wawancara, dan dokumentasi. Teknik analisis data yang digunakan dalam penelitian ini adalah analisis data kualitatif dan kuantitatif. Analisis data kualitatif yang digunakan adalah reduksi data, display data, dan verifikasi. Analisis data kuantitatif digunakan untuk mengetahui persentase kenaikan kemampuan membaca permulaan anak setelah pelaksanaan tindakan dengan menggunakan grafik. Hasil penelitian menunjukkan adanya peningkatan pemahaman geometri anak dapat dilihat dari prasiklus nilai rata-rata 58, siklus I nilai rata-rata 77 , dan siklus II dengan rata-rata 90. Sehingga dapat disimpulkan bahwa Kegiatan mendongeng dengan variasi media dapat meningkatkan kemampuan membaca permulaan.
\end{abstract}

Kata Kunci: Kemampuan Membaca Permulaan, Mendongeng, Media Variasi 
Masa usia dini merupakan rentangan usia peka, di mana dalam masa tersebut potensi anak akan berkembang sesuai dengan lingkungan tempat anak berada. Oleh karena itu tugas guru dan orang tua untuk mengembangkan potensi anak seoptimal mungkin dengan cara menyediakan lingkungan berupa kegiatan yang sesuai dengan perkembangan anak. Salah satu potensi anak yang sangat perlu diperhatikan adalah potensi penalarannya terhadap moral. Penalaran anak terhadap moral akan mempengaruhi pembentukan karakternya. (Aisyah, dalam sitia@mail.ut.ac.id : 2008)

Salah satu cara terbaik untuk membesarkan anak agar menjadi orang dewasa yang bahagia dan produktif adalah dengan memberikan kode moral sebagai dasar kehidupan mereka, sebuah dasar kepercayaan kukuh untuk memberikan tuntunan batin yang diperlukan dalam membuat pilihan dan menghadapi tantangan kehidupan. (Miller, 2003 : 17) Anak merupakan anugerah terindah bagi setiap orangtua. Namun, ketika anak beranjak remaja atau dewasa, bisa jadi anak yang telah dibesarkan dan dididik sebaik mungkin, menjadi anak yang tidak mengerti nilai-nilai moral dalam kehidupan. Kondisi tersebut tentu saja mengecewakan karena apa yang sejak dini ditanamkan, hilang begitu saja. Padahal, membentuk moral anak bisa dilakukan sejak dini, bahkan ketika anak memasuki tahun pertama usianya. (dalam http://lifestyle.okezone.com:2007).Membent uk moral anak bisa dilakukan lewat story telling (dongeng). Kegiatan membaca dongeng dan berdiskusi antara orangtua dan anak ini dapat dilakukan di rumah.

Metode bercerita merupakan salah satu metode yang banyak digunakan dalam mendidik anak. Bercerita merupakan salah satu pemberian pengalaman belajar bagi anak-anak dengan membawakan cerita kepada anak secara lisan. Cerita yang dibawakan harus menarik, mengundang perhatian anak dan tidak lepas dari tujuan pendidikan bagi anak. (Hidayat, 2008 : 4.18) Dongeng mungkin sudah jarang dilakukan. Bahkan beberapa orangtua atau guru seringkali kesulitan dalam membuat dongeng. Ada juga yang malas mendongeng karena kurangnya pengetahuan tentang dongeng, dan tidak peduli terhadap anak. Dengan banyaknya membaca literatur, maka guru atau orangtua dapat menguasai dongeng, sehingga semakin rajin untuk menyampaikan cerita kepada anak-anak.

Mendongeng boleh jadi terdengar tidak penting. Tapi dengan kesibukan orang tua di luar rumah, kebiasan mendongeng menjadi hal yang sangat berarti bagi anak. Mendongeng tidak harus lama, melainkan bagaimana isi dongeng itu dapat bermanfaat dan mudah dimengerti bagi anak. Dan sesungguhnya kebiasaan mendongeng orang tua kepada anak memiliki banyak manfaat. Kegiatan mendongeng tak hanya membawa dampak positif bagi anak, tetapi juga bagi pendongengnya, dalam hal ini orang tua maupun guru. (dalam http://www.koranjakarta.com : 2010) Pada orang tua, kebiasaan mendongeng membawa dampak emosional. Dengan demikian, setidaknya anak akan merasa dekat dengan orang tuanya. Menurut Fridani, pengajar program studi Pendidikan Anak Usia Dini (PAUD) di Universitas Negeri Jakarta (dalam http://www.koran-jakarta.com: 2010) menjelaskan kegiatan atau aktivitas mendongeng yang dilakukan dengan cara yang tepat dapat mengembangkan berbagai aspek perkembangan dari anak tersebut yang akan sangat penting d1alam proses perkembangan anak itu sendiri. Aspek perkembangan tersebut di antaranya aspek bahasa, intelektual, emosi sosial, termasuk juga moral dan agama.

Dunia anak adalah dunia bermain dan bercerita. Anak-anak lebih mudah menyerap pendidikan melalui bermain dan bercerita. Sayangnya, hanya sedikit orangtua dan guru yang menguasai teknik bermain dan bercerita dengan baik. Maka, wajar jika anak lebih asyik bermain sendiri dan tidak mendengarkan katakata orang tua dan gurunya. Padahal, mendongeng tidak membutuhkan bakat dan ketrampilan khusus. Karena mendongeng dapat dilakukan oleh siapapun dan kapanpun. (Asfandiyar, 2009)

Menurut Sari (2010 : 3), dongeng juga dapat menjadi salah satu media komunikasi untuk menyampaikan beberapa pelajaran atau 
pesan moral kepada anak. Tidak ada batasan usia kapan anak mulai boleh mendengarkan dongeng. Bahkan anak dapat dibacakan dongeng sejak dalam kandungan sebagai salah satu cara untuk orangtua menjalin komunikasi dengan calon anaknya. Apalagi untuk anak usia dini, dapat mendengar cerita sederhana misalnya tentang cerita hewan. Masih menurut Sari, kegiatan mendongeng sebenarnya juga bisa memikat dan mendatangkan banyak manfaat. Bukan hanya untuk anak-anak namun juga untuk orangtua yang mendongeng untuk anaknya. Kegiatan ini dapat mempererat ikatan dan komunikasi yang terjalin antara orangtua dan anak. Anak-anak memperoleh banyak hal dari cerita. Orang dewasa pun mendapat banyak hal dari bercerita. Apa yang orang dewasa lakukan dengan bercerita pada anakanak mereka adalah upaya memberikan segala yang terbaik untuk perkembangan anak-anak tersebut. Para pakar menyatakan bahwa banyak sekali manfaat kegiatan dongeng ini bagi anak. Dongeng merupakan salah satu cara yang efektif dalam mendidik anak untuk menyampaikan sentuhan manusiawi dan nilai sportivitas pada anak. Setiap orang bisa bercerita, baik cerita tentang pengalaman pribadi, pengalaman orang lain atau dari kisahkisah. Ada yang menggunakan alat peraga sebagai media, ada yang dengan mimik atau gerakan tertentu, dengan kata lain setiap orang memiliki ciri khas yang berbeda dalam mendongeng.

Dongeng memiliki daya tarik yang kuat yang dapat mengubah perhatian seseorang bahkan orang dewasa sekalipun. Dongeng sangat mudah masuk ke area pemikiran seseorang, apalagi anak-anak. Karena sifatnya yang bebas dari segala tuntutan inilah, akan membuat anak semakin menyukai dunia dongeng. Bahkan menurut Ars (dalam Latif, 2009 : 1) menjelaskan bahwa kegiatan mendongeng sebenarnya tidak sekedar bersifat hiburan belaka, melainkan memiliki tujuan yang lebih luhur, yakni pengenalan alam lingkungan, budi pekerti dan mendorong anak berperilaku positif. Dongeng sering diidentikkan sebagai suatu cerita bohong, bualan, khayalan atau cerita yang mengada-ada dan tidak ada manfaatnya. Bahkan ada yang menganggap dongeng sebagi cerita yang tidak masuk akal. Memang benar dongeng adalah cerita rekaan, tetapi tidak berarti dongeng itu tidak bermanfaat. (Asfandiyar, 2009:19)

Bahkan menurut Samson dan Supangat (dalam Harini dan Al-Halwani, 2003 :132) menjelaskan bahwa anak kecil (prasekolah) amat senang mendengarkan dongeng. Bercerita merupakan suatu proses kreatif anak-anak. Dalam perkembangannya, dongeng senantiasa mengaktifkan tidak hanya aspek-aspek intelektual, tetapi juga aspek kepekaan, kehalusan budi, emosi, seni, fantasi, dan imajinasi, tidak hanya mengutamakan otak kiri, namun juga otak kanan. (Asfandiyar, 2009:19)

Masih menurut Asfandiyar, cerita atau dongeng menawarkan kesempatan menginterpretasi dengan mengenali kehidupan di luar pengalaman langsung mereka. Anakanak dikenalkan pada berbagai cara, pola, dan pendekatan tingkah laku manusia sehingga mereka mendapat bekal menghadapi masa depan. Untuk mewujudkan hal tersebut, kesungguhan, ketulusan, dan kasih sayang orangtua dalam bercerita atau mendongeng mutlak diperlukan. Menurut Ariyani (dalam Harini dan Al-Halwani, 2003 : 136) menjelaskan bahwa anak akan merasa senang apabila diberi dongeng tentang binatang yang dapat berbicara seperti manusia atau dongeng tentang pengalaman hidup atau petualangan. Dongeng yang berisi kekejaman akan mempunyai pengaruh yang buruk bagi anak. Anak akan mengalami mimpi-mimpi buruk dan menjadi sangat ketakutan. Secara tidak langsung mendongeng merupakan suatu kesempatan yang baik untuk mengajarkan sesuatu kepada anak. Dongeng akan membuat anak mengerti hal-hal yang baik dan yang buruk, yang boleh diperbuat dan yang tidak boleh diperbuat.. 
Kondisi di KB PAUD PKK Wonojoyo tahun ajaran 2015/2016 ini merupakan anakanak yang unik. Dalam satu kelas berisi 16 orang anak dengan 2 pengajar. Beberapa anak masih belum mampu dalam membaca suka memaksakan kehendaknya, serta terkadang memukul temannya bila tidak sesuai dengan apa yang dikehendaki. Pada akhirnya, karena perilaku alamiah anak yang suka meniru, temannya pun ikut berbuat yang sama. Sehingga kondisi kelas seringkali gaduh karena ada anak-anak yang memaksakan kehendak dan atau memukul temannya. Pengajar pun sering menasehati mereka dengan cara meminta maaf bila melakukan kesalahan, namun tetap saja keesokan harinya melakukan kesalahan dengan mengganggu temannya lagi. Kondisi yang seperti ini memunculkan sebuah ide bagi penulis untuk melakukan penelitian untuk melihat menerapkan kegiatan mendongeng dalam rangka meningkatkan kemampuan membaca permulaan anak usia dini.

Berdasarkan hal-hal tersebut maka peneliti mengangkat penelitian dengan judul "Meningkatkan Kemampuan Membaca Permulaan Melalui Kegiatan Mendongeng Dengan Variasi Media di KB PAUD

\section{Pengertian Mendongeng}

Menurut Asfandiyar (2009 : 19), dongeng sering diidentikkan sebagai suatu cerita bohong, bualan, khayalan, atau cerita yang mengada-ada dan tidak ada manfaatnya. Bahkan, ada yang menganggap dongeng sebagai cerita yang tidak masuk akal. Memang benar, dongeng adalah cerita rekaan, tetapi tidak berarti dongeng itu tidak bermanfaat. Sedangkan menurut Latif (2009 : 3), mendongeng berbeda dengan bercerita. Bercerita adalah suatu seni dalam menyampaikan ilmu, pesan, nasihat kepada orang lain, baik anak-anak, remaja, dewasa, maupun orang tua. Sebagian besar bahannya berdasarkan fakta, dengan bahasa yang datar dan baku. Sedangkan mendongeng lebih banyak disisipi khayalan yang dikembangkan dengan menarik.

Sejalan dengan Latif menurut Harini dan Al-Halwani (2003 : 133) dongeng adalah wadah yang mendukung usaha orang untuk memahami perasaan dan khayalannya. Sedangkan menurut Sari (2009 : 3) dongeng adalah salah satu media komunikasi guna menyampaikan beberapa pelajaran atau pesan moral pada anak.

Mendongeng merupakan cara bercerita yang meneruskan warisan budaya dari suatu generasi ke generasi berikutnya. Dapat dikatakan mendongeng merupakan teknik bercerita yang telah dikenal paling lama. Selain dapat dipergunakan untuk menyampaikan pesan-pesan kebajikan kepada anak, juga dapat mengenalkan daerah, budaya, adat istiadat dari tempat dongeng itu berasal. Oleh karena itu, dongeng perlu dipertahankan dalam kehidupan anak. (Montolalu, 2005 : 10.4)

Berdasarkan berbagai pendapat di atas, maka penulis dapat menyimpulkan bahwa mendongeng merupakan warisan budaya berisikan cerita khayalan yang menarik dan berguna untuk menyampaikan pesan moral kepada anak

\section{Jenis-jenis Dongeng}

Menurut Asfandiyar (2009 : 85), jenisjenis dongeng yaitu :

1. Dongeng Tradisional

Dongeng tradisional adalah dongeng yang berkaitan dengan cerita rakyat dan biasanya turun temurun. Dongeng ini sebagian besar berfungsi untuk melipur lara dan menanamkan semangat kepahlawanan. Biasanya, dongeng tradisional disajikan sebagi pengisi waktu istirahat, dibawakan secara romantis, penuh humor, dan sangat menarik. Misalnya, Malinkundang, Calon Arang, Momotaro, Jaka Tingkir, Sangkuriang, dan lain-lain. 
2. Dongeng Futuristik (Modern)

Dongeng futuristik atau dongeng modern disebut juga dongeng fantasi. Dongeng ini, biasanya bercerita tentang sesuatu yang fantastik, missal tokohnya tiba-tiba menghilang. Dongeng futuristik bisa juga bercerita tentang masa depan, misalnya, Bumi Abad 25, Star Trek, Back to the Future, dan Jumanji.

3. Dongeng Pendidikan

Dongeng pendidikan adalah dongeng yang diciptakan dengan suatu misi pendidikan bagi dunia anak-anak. Misalnya, menggugah sikap hormat kepada orang tua.

\section{Fabel}

Fabel adalah dongeng tentang kehidupan binatang yang digambarkan bisa berbicara seperti manusia. Cerita-cerita fabel sangat luwes digunakan untuk menyindir perilaku manusia tanpa membuat manusia tersinggung. Misalnya, dongeng kancil, kura-kura dan kelinci, dan lain-lain.

5. Dongeng Sejarah

Dongeng sejarah biasanya terkait dengan suatu peristiwa sejarah. Dongeng ini, banyak yang bertemakan kepahlawanan. Misalnya, kisah-kisah para sahabat Rosululloh SAW, sejarah perjuangan Indonesia, sejarah pahlawan atau tokoh-tokoh, dan sebagainya.

\section{Dongeng Terapi (Traumatic Healing)}

Dongeng terapi (traumatic healing) adalah dongeng yang diperuntukkan bagi anak-anak korban bencana atau anak-anak yang sakit. Dongeng terapi, adalah dongeng yang bisa membuat rileks saraf-saraf otak dan membuat tenang hati mereka. Oleh karena itu, dongeng ini didukung pula oleh kesabaran pendongengnya dan musik yang sesuai dengan terapi itu sehingga membuat anak merasa nyaman dan enak.

\section{Manfaat Kegiatan Mendongeng}

Cerita atau dongeng bagi anak prasekolah mempunyai nilai pendidikan yang sangat besar. Menurut Ma'sumah (dalam Harini dan Al-Halwani, 2003 : 136) cerita atau dongeng bagi anak prasekolah mempunyai manfaat sebagai berikut :

1. Cerita atau dongeng bermanfaat bagi perkembangan pengamatan, ingatan, fantasi, dan pikiran anak.

2. Bahan cerita atau dongeng yang baik dan terpilih sangat berguna sekali untuk pembentukan budi pekerti anak.

3. Bentuk cerita atau dongeng yang tersusun baik dan cara penyajiannya juga baik akan menambah perbendaharaan bahasa.

Dongeng merupakan salah satu cara yang efektif untuk mengembangkan aspekaspek kognitif (pengetahuan), afektif (perasaan), sosial dan konatif (penghayatan). Selain itu, dongeng pun dapat membawa anakanak pada pengalaman-pengalaman baru yang belum pernah dialaminya. (Asfandiyar, 2009 : 23) Tanpa disadari, orang tua (khususnya ibu) yang sering membacakan atau bercerita kepada anak-anaknya membacakan atau bercerita kepada anak-anaknya sejak kecil, ternyata mampu menciptakan anak-anak yang mencintai buku dan gemar membaca ketika mereka sudah besar.

Mereka suka membaca karena lingkungan sekelilingnya senantiasa merangsangnya melalui pendekatan visual dengan memperkenalkan buku secara fisik, kemudian membacakan atau menceritakannya. Hal inilah yang membuat anak termotivasi untuk lebih jauh mendalam buku sehingga suatu saat buku buku menjadi sebuah kebutuhan. Bagi anak-anak, menikmati dongeng sama menariknya dengan bermain. Dongeng berkaitan dengan naluri merangsang 
daya fantasi dan imajinasi untuk pengembangan kreativitas. Setelah mendengarkan dongeng, anak-anak dapat mengembangkan imajinasinya melalui tulisan atau gambar.

Mereka dapat berimajinasi dan berkreasi dengan bebas. Apa yang mereka dengar, apa yang mereka asosiasikan, dan apa yang mereka pikirkan dapat dituangkan sesuka hati demi membekali diri menghadapi hari depan penuh tuntutan kreativitas dan profesionalisme. Mereka semua tentu akan menghasilkan karya yang baik sesuai dengan daya serap dan kesiapan mereka menyerap cerita atau dongeng yang disampaikan. Anak-anak yang didongengi, semua indranya akan aktif, hatinya aktif, dan otaknya aktif, sehingga apa yang mereka dapat dari pendongeng berupa suara, ucapan, gerak, gambar, mungkin juga baubauan, akan membuat mereka banyak belajar. Kecerdasan suaranya terpacu, kecerdasan visualnya terpacu, kecerdasan emosionalnya terpacu, interpersonalnya juga terpacu ketika cerita itu berkaitan dengan kerjasama.

Semua itu terbangunkan walaupun dengan kadar yang berbeda-beda. Anak yang suka didongengi secara terus-menerus, semua kecerdasannya akan terasah. Walaupun kadarnya tidak rata, semuanya ada dan menonjol. Demi anak, dongeng hendaknya diterima sebagai alat pemersatu dan pembawa bahagia. Dalam diri pencerita yang tulus, akan lahir manfaat dan nilai. Kita percaya bahwa kasih sayang adalah hal utama dalam berurusan dengan anak, bahkan manusia. Bukan hanya karena manfaatnya, namun bagaimana mereka bahagia, itulah yang pertama diberikan oleh kegiatan mendongeng.

Anak merasakan kehangatan karena dapat bersama-sama dengan pencerita. Anak bersama pencerita dapat berkelana, memahami, dan merasakan pedih dan gembiranya kehidupan. Pada dasarnya, bercerita adalah kegiatan berbagi rasa, membuka diri secara tulus, menyampaikan perasaan, mengungkapkan nilai-nilai, dan menyampaikan pengalaman dengan sungguhsungguh sehingga dapat diterima dan diserap oleh anak-anak. Anak-anak membuka seluruh alat penyerap informasi lebar-lebar dan sungguh-sungguh. Otak kiri, otak kanan, dan jiwanya berfungsi dengan optimal. Bisa jadi, bercertita adalah hiburan termudah dan termurah yang bisa kita lakukan.

\section{Teknik Mendongeng}

Menurut Agus (dalam Latif, 2009 : 65), ada beberapa hal yang harus diperhatikan agar menjadi pendongeng yang baik yaitu :

1. Memastikan kondisi fisik benar-benar dalam keadaan baik

Kondisi fisik adalah salah satu kunci sukses untuk menjadi pendongeng yang baik karena ketika kondisi kita tidak baik maka dalam penyampaian dongeng tidak akan sempurna.

2. Berusaha untuk memfokuskan perhatian pada cerita

Fokus tentang materi yang kita ceritakan karena bisa jadi ketika tidak fokus pada cerita, cerita yang kita bawakan akan lari ke mana-mana.

3. Menghayati cerita dengan sungguhsungguh

Bercerita tanpa penghayatan akan terasa kurang menarik sehingga pendongeng harus mampu menghayati cerita dengan sungguh-sungguh. Kalau ada peran menangis, maka pendongeng harus menghayatinya seolah-olah ia sedang menangis.

4. Membuat singkatan cerita

Kalau cerita itu susah dihafal, maka kita bisa membuat singkatan tentang pokok dari cerita tersebut. Selanjutnya kita tinggal improvisasi saja (menambahkan dengan dialog atau diskusi).

5. Menyiapkan dan menyusun gambargambar peraga 
6. Mendongeng untuk anak-anak di bawah lima tahun sangat baik menggunakan alat peraga, baik dengan boneka, kardus, atau dengan media lainnya. Agar tokoh yang kita peragakan tidak tertukar, maka kita harus menyusunnya terlebih dahulu sehingga mendongeng akan lebih mudah dan lancar

\section{Kemampuan Membaca Permulaan}

Membaca merupakan proses belajar yang membutuhkan waktu bagi anak-anak, terlebih bagi anak-anak usia preschool atau Pendidikan Anak Usia Dini (PAUD). Anakanak pada pendidikan di Taman Kanak-Kanak secara bertahap diberi kegiatan-kegiatan berupa permainan untuk mengembangkan fisik anak, sehingga tidak heran jika keadaan Taman Kanak-Kanak lebih diwarnai dengan permainan-permainan yang dapat merangsang anak untuk mencobanya. Secara tidak langsung dikatakan bahwa permainan yang bersifat melatih fisik anak bertujuan untuk mengembangkan aktivitas fisik anak tersebut.

Permainan, selain melatih fisik juga sekaligus melatih keberanian, keterampilan, keseimbangan serta saling mengadakan kontak sosial dengan anak lainnya. Hal ini sesuai dengan pendapat Moeslichatoen, bahwa bermain merupakan tuntutan dan kebutuhan yang esensial bagi anak TK. Melalui bermain, anak akan dapat memuaskan tuntutan dan kebutuhan perkembangan dimensi motorik, kognitif, kreativitas, bahasa, emosi, sosial, nilai, dan sikap hidup. Lebih lanjut dikemukakan bahwa melalui kegiatan bermain anak dapat mengembangkan kemampuan bahasa dengan cara mendengarkan beraneka bunyi, mengucapkan suku kata atau kata, memperluas kosa kata, berbicara sesuai tata bahasa Indonesia, dan sebagainya. (Moeslichatoen R, 1999: 32) Berdasarkan pendapat tersebut, dijelaskan bahwa bermain tidak hanva mengembangkan kemampuan fisik saja, namun juga mengembangkan kemampuan kognitif, kreativitas, bahasa, emosi, sosial, nilai, dan sikap hidup.

Pentingnya permainan bagi anak TK, sesuai dengan Vygotskv's, bahwa permainan merupakan aktivitas yang sangat penting untuk perkembangan anak usia 3-6 tahun. Dipercaya bahwa pada kelompok usia ini, permainan memiliki aturan vang unik dan tidak dapat diganti dengan aktivitas lainnya, sekalipun macam-macam pengalaman menguntungkan bagi anak pada periode ini. Pendapat ini menjelaskan bahwa bermain memiliki posisi penting dalam dunia anak sehingga hal ini tidak dapat diganti dengan aktivitas lain walaupun berbagai pengalaman menguntungkan bagi anak.

Berdasarkan analisis pendapat-pendapat di atas, maka pengembangan kemampuan membaca dan menulis khususnya di TK dapat diupayakan melalui pendekatan pengalaman berbahasa. Pengalaman ini didasarkan pada kemampuan berbahasa lisan seorang anak. Pendekatan ini dirasakan sangat penting sebagai kondisi awai proses belajar mengajar, mengingat proses ini selalu didahului dengan pengalaman anak sejak dini yang diungkapkan melalui ekspresi bahasa secara lisan. Hal ini sesuai dengan pendapat Spodek, Saracho, and Davis, bahwa pendekatan pengalaman berbahasa merupakan cara untuk mengekspresikan ide-ide anak sampai menjadi bahasa tertulis (Spodek, Saracho, and Davis, 1998 278). Dengan demikian melalui pengalaman berbahasa, anak akan memperoleh kesempatan untuk mengekspresikan berbagai ide atau gagasan yang dimilikinya. Kesempatankesempatan ini memberikan pengalaman berharga bagi anak untuk mengembangkan kemampuan yang dimiliki khususnya membaca dan menulis.

Pendekatan pengalaman berbahasa dalam sistem komunikasi dikatakan sebagai pendekatan yang mengintegrasikan aspek kebahasaan, yakni menyimak, berbicara, membaca, dan menulis dengan menggunakan berbagai materi dan aktivitas yang dikaitkan 
dengan dunia pergaulan anak itu sendiri. Keempat kemampuan berbahasa ini klasifikasinya didasarkan pada pemerolehan bahasa dan perkembangan anak. Secara alamiah, anak-anak memperoleh kemampuan menyimak bahasa atau ujaran-ujaran yang ada disekitarnya. Hal ini dijadikan potensi awai yang perlu dikembangkan untuk mendapatkan potensi kebahasaan berikutnya, yakni dengan mengembangkan kemampuan berbicara. Melalui dua aspek kemampuan bahasa ini dapat dijadikan sebagai penunjang dalam mengembangkan kemampuan membaca dan menulis.

Pendekatan pengalaman berbahasa pada dasarnya merupakan pendekatan pengajaran awal yang menekankan seberapa banyak lingkungan pergaulan yang anak lakukan sebagai bahan pengajaran. Pengalaman dalam hal ini sangat penting karena didasarkan pada pengalaman anak sehingga memiliki konsep yang akhirnya akan diwujudkan dalam bentuk bahasa. Hal ini disebabkan pengalaman sendiri atau belajar atas kemauan sendiri akan lebih mudah dipahami dan menarik serta akan lebih mudah tertanam dalam pikiran. Melalui pendekatan berbahasa, anak berperan aktif dalam pengalaman bersama. Hal ini dapat dilakukan dengan menggunakan berbagai permainan sesuai dengan karakteristik pembelajaran di TK. Pada berbagai aktivitas ini, maka anak pada kegiatan selanjutnya akan membaca dan menulis secara langsung dan mengulanginya. Pendekatan pengalaman anak ini akan seiring dengan tingkat perkembangan kognitif anak.

Pengembangan kemampuan berbahasa khususnya kemampuan membaca permulaan menurut Purwanto dan Alim diutamakan pada: (a) memberikan kecakapan kepada siswa untuk mengubah rangkaian bunyi bermakna, (b) melancarkan teknik membaca pada anak-anak. Sementara menurut Leonhardt, untuk dapat mengembangkan kemampuan membaca perlu pelatihan, membaca perlu praktik yang dilakukan secara berulang, dan nembaca perlu pembiasaan. Dengan adanya kegiatan membaca yang dilakukan secara berulang akan melahirkan suatu kebiasaan yang positif pada diri anak hingga menjadi kegemaran. Kegemaran anak ini tentunya akan mendorong anak untuk terus belajar membaca dan menulis.

Mengingat pendekatan pengalaman berbahasa merupakan suatu pendekatan yang dapat mengembangkan kemampuan membaca dan menulis, maka pendekatan ini diberikan melalui berbagai bentuk kegiatan atau permainan. Dengan demikian, melalui berbagai kegiatan atau permainan yang tentunya sesuai dengan perkembangan dan kebutuhan anak akan memberikan pengalaman berbahasa bagi anak sehingga hal ini akan memberikan kesempatan kepada anak untuk mengembangkan kemampuan khususnya membaca dan menulis. Berdasarkan uraian tersebut, pendekatan ini dapat dijadikan sebagai suatu strategi yang harus digunakan guru dalam mengembangkan kemampuan membaca dan menulis anak usia dini.

\section{METODE}

Metode penelitian yang dipilih adalah penelitian tindakan (action reserach). Model penelitian tindakan Kemmis dan Mc. Taggart dengan tahapan perencanaan, Pelaksanaan, Observasi, dan Refleksi. Teknik pengumpulan data yang digunakan dalam penelitian ini yaitu: (1) Pengamatan, (2) Catatan Lapangan, dan (3) Dokumentasi. Analisis data dilakukan secara kuantitatif dan kualitatif.

Instrumen Penelitian yang digunakan sebagai alat pengumpul data dalam penelitian tindakan ini adalah instrumen non tes yakni dengan menggunakan pengamatan atau observasi yang mengacu pada pemahaman geometri. Analisis data secara kuantitatif dilakukan dengan melihat adanya persentase peningkatan pemahaman geometri mulai dari pra-intervensi, siklus I sampai siklus II dengan 
menggunakan grafik. Sedangkan analisis data kualitatif dilakukan dengan cara menganalisis data dari hasil catatan lapangan dan catatn dokumentasi selama penelitian. Secara kualitatif, berdasarkan penyusunan data menurut Miles dan Huberman, tahapan yang dilalui yaitu reduksi data, display data dan verifikasi.

\section{HASIL DAN PEMBAHASAN}

Penelitian ini diawali dengan kegiatan observasi awal yang dilakukan oleh peneliti untuk mengetahui bagaimana proses pembelajaran yang dilakukan oleh guru di KB PAUD PKK Wonojoyo. Sebelum pemberian tindakan diadakan penilaian pra siklus guna mengetahui pemahaman kemampuan membaca permulaan. Proses pelaksanaan pembelajaran melalui pendekatan project based learning menunjukkan adanya peningkatan pada indikator-indikator kemampuan memebaca permulaan. Hal tersebut terlihat dari hasil observasi pemantau tindakan yang menunjukkan bahwa guru telah melaksanakn seluruh aktifitas kegiatan sesuai dengan skenario kegiatan yang telah dibuat serta hasil asesment anak saat kegiatan mendongeng dilaksanakan.

\section{Pra Intervensi}

Berdasarkan hasil pra tindakan yang dilakukan oleh peneliti di KB PAUD PKK Wonojoyo ditemukan permasalahan bahwa kemampuan membaca permulaan ,asoh remdah. Dari 16 anak dimana terdiri dari 4 anak laki-laki dan 12 anak perempuan sebagian besar belum mampu membaca huruf. Hal ini terlihat dari data pra intervensi, dalam data tersebut menunjukkan bahwa kemampuan membaca permulaaan anak belum mencapai TCP yang disepakati.

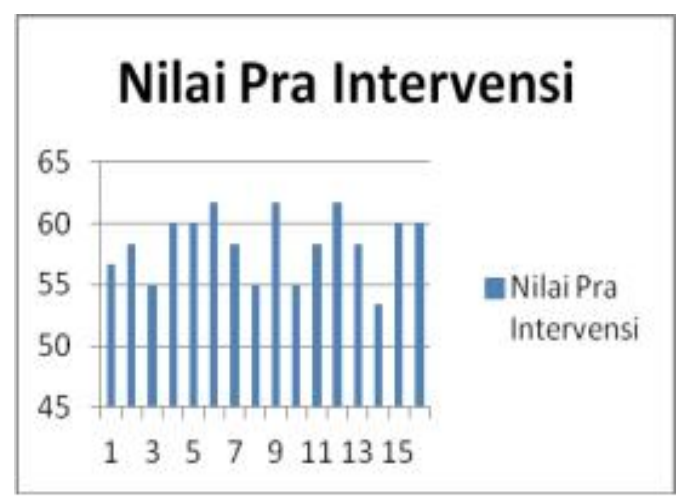

\section{Gambar 1 \\ Grafik Kemampuan Membaca Prmulaan Pra Intervensi}

Grafik kemampuan membaca permulaan pra intervensi tersebut menggambarkan bahwa rata-rata skor kemampuan membaca permulaan anak pada pra intervensi dengan skor rata-rata 35 atau 58. Jumlah anak 16 di kelompok B menunjukkan bahwa skor terendah yaitu 32 atau 53 dan skor tertinggi sebesar 37 atau 62 . Hal ini berarti belum sesuai target yang disepakati

\section{Siklus I}

Pada siklus I sebanyak delapan anak memiliki persentase di atas rata-rata kelas. Sedangkan delapan anak belum mencapai standar keberhasilan tindakan yang diharapakan. Dengan demikian persentase kenaikan belum mencapai standar keberhasilan $71 \%$ jumlah keseluruhan anak seperti yang diungkap Mills. Sehingga dapat disimpulkan persentase dari pra siklus sampai siklus I kemampuan membaca permulaan anak belum mencapai standar keberhasilan $71 \%$ jumlah keseluruhan anak sehingga perlu dilakukan tindakan pada siklus 2. Karena peneliti juga merujuk pada standar keberhasilan penelitian ini dikatakan berhasil jika $71 \%$ dari keseluruhan anak sudah mencapai standar keberhasilan yang disepakati oleh sekolah dan kolaborator yaitu sebesar 75 


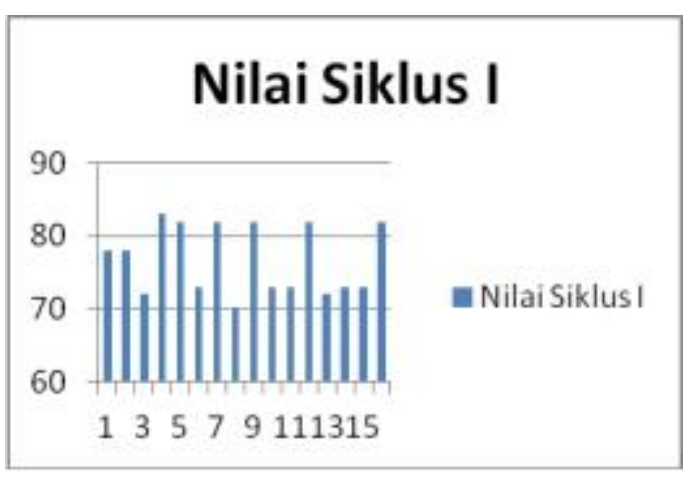

Gambar 2

Grafik Ra-rata

Kemampuan Membaca Permulaan Melalui Kegiatan Mendogeng Siklus I

Grafik tersebut menggambarkan bahwa ratarata skor kemampuan membaca permulaan melalui kegiatan mendongeng. Jumlah anak 16 orang di kelompok B menunjukkan bahwa skor terendah sebesar 42 atau 70 dan skor tertinggi sebesar 50 atau 83.

\section{Siklus II}

Pada siklus II skor kemampuan membaca permulaan anak sudah sesuai dengan standart kesepakatan antara peneliti dan kolaborator. Hal ini terlihat dari peningkatan dari siklus I ke siklus II mengalami peningkatan sebesar 13 .

Hal tersebut terlihat dari hasil pengamatan sebelum dan sesudah tindakan pada siklus II yang disesuaikan dengan indikator kemampuan Membaca. Berdasarkan peningkatan kemampuan membaca permulaan anak yang didapat pada akhir siklus II, peneliti dan guru menyimpulkan bahwa peningkatan yang dihasilkan dari pra intervensi sampai siklus II sudah memenuhi standart yang disekati sebelumnya yaitu sebesar 45 atau 75 . Dengan demikian peneliti dan guru menghentikan penelitian ini karena peningkatan sudah sesuai dengan yang diharapkan.

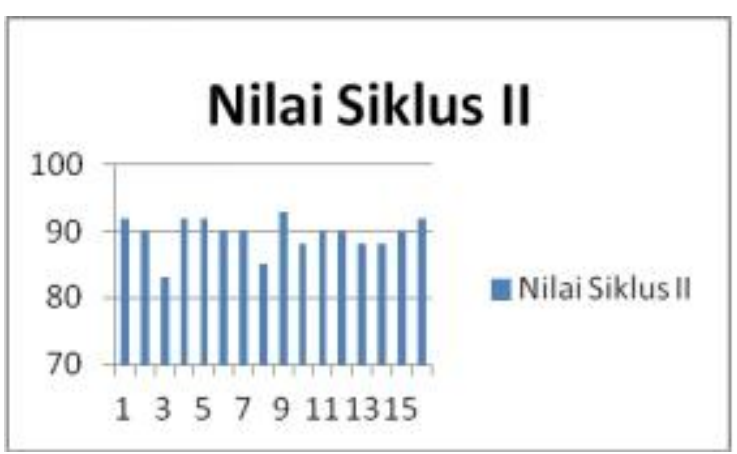

\section{Gambar 3}

Grafik Ra-rata

Kemampuan Membaca Permulaan Melalui Kegiatan Mendogeng Siklus I

Grafik tersebut menggambarkan bahwa ratarata skor kemampuan membaca permulaan. Jumlah anak 16 orang di kelompok B menunjukkan skor terendah sebesar 50 atau 83 dan skor tertinggi sebesar 56 atau 93.

\section{SIMPULAN}

Berdasarkan hasil analisis data dan pembahasan pada penelitian tindakan yang berjudul Meningkatkan kemampuan membaca permulaan Melalui Kegiatan Mendongeng Dengan Variasi Media di KB PAUD PKK Wonojoyo Kediri dapat diambil kesimpulan sebagai berikut: kemampuan membaca permulaan Melalui Kegiatan Mendongeng Dengan Variasi Media di KB PAUD PKK Wonojoyo Kediri dapat meningkat.. Pada siklus I kemampuan membaca permulaan indikator anak membaca huruf masih $r$ rendah, sehingga belum mencapai standart yang disepakati antara sekolah dan kolaborator, sehingga dilanjutkan pada siklus II. Pada siklus II ini semua indikator sudah mencapai target yang diinginkan, dan kemampuan membaca permulaan semua anak sudah meningkat. Kegiatan mendongeng dapat meningktan kemampuan membaca permulaan anak KB PAUD PKK Wonojoyo. Peningkatan tersebut dapat dilihat dari hasil sebelum dilakukan tindakan pra intervensi adalah rata-rata 58, siklus I dengan rata-rata 77 dan siklus II dengan rata-rata 90. 


\section{DAFTAR PUSTAKA}

Aisyah, S. Mengembangkan Karakter Anak Usia Dini Melalui Kegiatan Bercerita. sitia@mail.ut.ac.id. Diakses online pada tanggal 28 Februari 2011

Chulsum, U., \& Windy., N. 2006. Kamus Besar Bahasa Indonesia. Surabaya : Kashiko.

Harini, S \& Aba., F., A. 2003. Mendidik Anak Sejak Dini. Yogyakarta : Kreasi Wacana.

Latif, M., A. 2009. The Power Of Story Telling : Kekuatan Dongeng terhadap Pembentukan Karakter Anak. Depok : PT. Luxima Metro Media.

Miller, J., C. 2003. Mengasah Kecerdasan Moral Anak Melalui Permainan 10 Menit. Terjemahan oleh Lovely. Bandung : Kaifa.

Montolalu, B., E., F., dkk. 2005. Materi Pokok Bermain dan Permainan Anak. Jakarta : Universitas Terbuka

Nur'aini, F. 2010. Membentuk Karakter Anak dengan Dongeng. Surakarta : Indiparent.

R., Moeslichatoen, 1999. Metode Pengajaran Di Taman Kanak-kanak. Jakarta : Rineka Cipta.

Sari, P., A. 2010. Dongeng Inspiratif untuk Anak Cerdas. Yogyakarta : Immortal Publisher.

Sukmadinata, N., S. 2009. Metode Penelitian Pendidikan. Bandung : PT. Remaja Rosdakarya.

.2008. Membentuk Moral Anak. http://lifestyle.okezone.com. Diakses online pada tanggal 28 Februari 2011.
.2010. Membentuk Moral Anak Melalui Mendongeng. http://www.koranjakarta.com. Diakses online pada tanggal 28 Februari 2011 